\title{
Migrations of the Caenorhabditis elegans HSNs are regulated by egl-43, a gene encoding two zinc finger proteins
}

\author{
Gian Garriga, ${ }^{1-3}$ Catherine Guenther, ${ }^{1}$ and H. Robert Horvitz ${ }^{2}$ \\ ${ }^{1}$ Department of Molecular and Cell Biology, University of California, Berkeley, California 94720 USA; ${ }^{2}$ Howard Hughes \\ Medical Institute, Department of Biology, Massachusetts Institute of Technology, Cambridge, Massachusetts 02139 USA
}

\begin{abstract}
During embryonic development, the two Caenorhabditis elegans HSN motor neurons migrate from their birthplace in the tail to positions near the middle of the embryo. Here, we demonstrate that of all cells that undergo long-range migrations, only the HSNs are affected in animals that lack function of the egl-43 gene. We also show that egl-43 function is required for normal development of phasmid neurons, which are sensory neurons located in the tail. The egl-43 gene encodes two proteins containing zinc finger motifs that are similar to the zinc fingers of the murine Evi-1 proto-oncoprotein. Our genetic and molecular results suggest that egl-43 encodes two transcription factors and acts to control HSN migration and phasmid neuron development, presumably by regulating other genes that function directly in these processes.
\end{abstract}

[Key Words: C. elegans; cell migration; zinc fingers; egl-43]

Received June 10, 1993; revised version accepted August 27, 1993.

During metazoan development, many cells migrate before they differentiate. Although cell migration is important for many aspects of development, the extent of the cell migration that occurs during the development of nervous systems is particularly striking. For example, populations of migrating cells generate much of the vertebrate peripheral nervous system (LeDouarin 1982). Neuronal precursors that migrate from the neural crest ventrally along different routes to various positions produce sensory, autonomic, and enteric neurons as well as glia, pigment cells, mesenchymal cells, and chromaffin cells of the adrenal medulla. Extensive cell migration also occurs during the development of the vertebrate central nervous system. Neuroblasts migrate radially from the ventricular zone, where they are born, past older neurons to more superficial layers of the cortex (Rakic 1974). Moreover, after reaching the appropriate cortical layer, many of these cells undergo extensive secondary migrations. For example, clonally related cells of the chick optic tectum migrate along three separate pathways, adopting distinct fates (Gray and Sanes 1991).

Although many studies have established that cell migrations play a major role during metazoan development, the mechanisms that regulate these migrations remain largely undefined. To identify the components involved in cell migration, investigators have taken two general approaches. Biochemical methods have been used to identify and characterize molecules that mediate cell migration and have been particularly successful in defin-

\footnotetext{
${ }^{3}$ Corresponding author.
}

ing cell surface and extracellular matrix molecules (for review, see Hatten 1990; Reichardt and Tomaselli 1991; Hynes and Lander 1992). An alternative strategy is to use genetic methods, which, in principle, should identify not only genes that encode cell-surface and extracellular matrix molecules but also genes that regulate and respond to these molecules to control the timing, direction, and extent of cell migration. Genetic studies of cell migration are particularly straightforward using the nematode Caenorhabditis elegans, because individual migrating cells can be observed directly in living, intact animals (Sulston and Horvitz 1977; Kimble and Hirsh 1979; Sulston et al. 1983). Many genes required for various $C$. elegans cell migrations have been identified /Chalfie et al. 1983; Kenyon 1986; Hedgecock et al. 1987,1990; Desai et al. 1988; Manser and Wood 1990; Stern and Horvitz 1992; Clark et al. 1992,1993; Wang et al. 1993).

With the goal of understanding in detail how a specific cell migrates, we are studying genes involved in the embryonic migrations of the hermaphrodite-specific neurons (HSNs), a pair of serotonergic motor neurons that control egg laying by the hermaphrodite (Desai et al. 1988). To date, 19 genes involved in these migrations have been identified (Desai et al. 1988; G. Garriga, L. Bloom, and H.R. Horvitz, unpubl.). Here we describe the genetic and molecular characterization of egl-43, a gene that plays a key role in HSN migration. Mutations in egl-43 result in the most severe HSN migration defect of all HSN migration mutants. Genetic results demonstrate that egl-43 is required for HSN migration but not for other cell migrations, indicating that this gene does 
not function globally in cell migration. Molecular analysis demonstrates that egl-43 encodes two proteins containing zinc finger motifs that are related to the zinc fingers of the murine Evi-1 proto-oncoprotein (Morishita et al. 1988). Our working model is that the egl-43 gene encodes two transcription factors that control HSN migration, presumably by regulating other genes that function directly in cell migration.

\section{Results}

\section{The egl-43 gene is required for HSN migration}

The C. elegans HSNs are a pair of serotonergic motor neurons that innervate the vulval muscles and stimulate egg laying by hermaphrodites (Desai et al. 1988). The two bilaterally symmetric HSNs are generated during embryogenesis and migrate anteriorly to the middle of the embryo from their birthplace in the tail (Fig. 1) (Sulston et al. 1983). Differentiation occurs later: The HSNs extend axons during larval development and synthesize serotonin in young adult hermaphrodites (Desai et al. 1988; Garriga et al. 1993).

Of the HSN migration mutants, egl-43 hermaphrodites exhibit the most severe defects in migration; the egl-43 HSNs migrate, on average, only $5-10 \%$ of the dis-

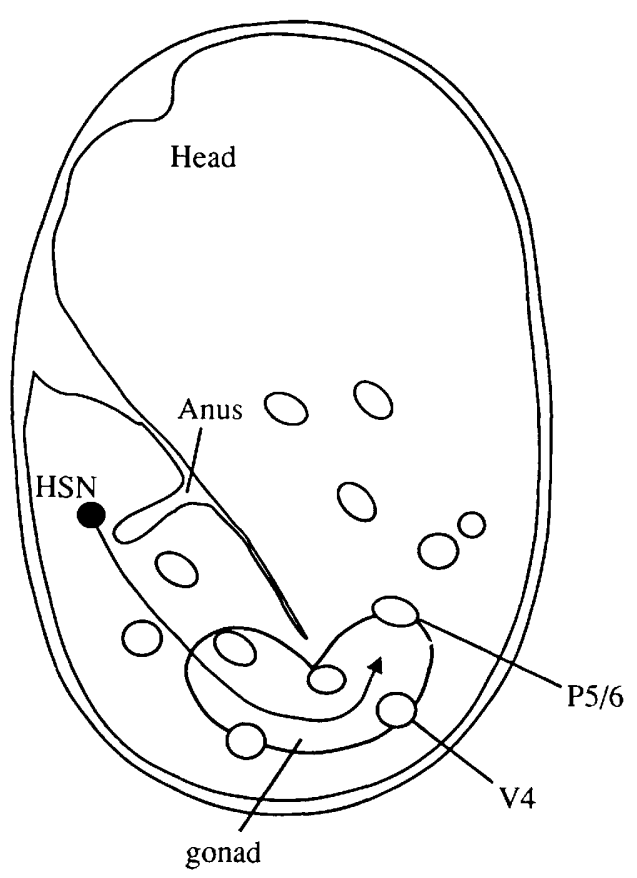

Figure 1. HSN migration. Schematic lateral view of an embryo 400 min after fertilization, at the time of the HSN birth. Only one of the two bilaterally symmetric HSNs is shown, and only a few of the other cells (indicated by circles and ovals) present at this time are shown. P5/6 and V4 are blast cells that divide postembryonically (Sulston and Horvitz 1977). The final position of the HSN is between P5/6 and V4. The arrow indicates the route of HSN migration; however, by the time the HSN arrives at its final destination, the embryo is much longer than shown here. After Sulston et al. (1983). tance normally traversed by wild-type HSNs (Desai et al. 1988). Figure 2 compares the positions of the HSNs in wild-type and egl-43(n1079) adult hermaphrodites. The egl-43 hermaphrodite shown in Figure $2 \mathrm{~b}$ exhibits the most extreme migration defect: The HSNs have failed to migrate from their birthplace in the tail.

Although migration is the only HSN trait that is severely disrupted in the two existing egl-43 mutants, axonal guidance and serotonin expression are also affected. As in the wild type, in egl-43 animals, each displaced HSN cell body extends a single axon to the ventral nerve cord (Garriga et al. 1993). Once in the ventral nerve cord, each axon turns anteriorly and extends to the head where it enters the nerve ring. Although these aspects of HSN axonal outgrowth are relatively normal in egl-43 mutants, the HSN axons fasciculate abnormally within the ventral nerve cord and fail to branch at the vulva (Garriga et al. 1993). In wild-type hermaphrodites, most of the synapses with the egg-laying muscles are made on this branch (White et al. 1986). Because all HSN migration mutants exhibit similar fasciculation and branching defects, the axonal guidance abnormalities of the egl-43 mutants presumably are secondary consequences of the posterior displacement of the HSN cell bodies (Garriga et al. 1993).

egl-43 mutants also exhibit a weak neurotransmitterexpression defect: Approximately $10 \%$ of the HSNs fail to stain with anti-serotonin antisera; other serotonergic neurons stain normally (Desai et al. 1988). Like the axonal-outgrowth defect, the serotonin-expression defect also might be a secondary effect of the misplacement of the HSN cell bodies. Alternatively, egl-43 might play a direct role in the expression of HSN serotonin. Consistent with the former possibility, other mutations that cause severe HSN displacements also result in low penetrance defects in HSN-serotonin expression (G. Garriga, unpubl.). Thus, although egl-43 mutants are abnormal in HSN migration, axonal outgrowth, and serotonin expression, migration might be the only HSN trait that is affected directly by the absence of the egl-43 gene product.

The egl-43 gene is required for phasmid neuron development

Mutations in the egl-43 gene also affect the development of the PHA and PHB phasmid neurons, which are sensory neurons that are located in the tail. When wild-type animals are soaked in certain fluorescent dyes, such as the carbocyanine dye Dil (1,1-dioctadecyl-3,3,3',3'-tetramethylindolecarbocynanine perchlorate; Molecular Probes, Inc.), PHA and PHB take up the dye through their exposed sensilla, and both their cell bodies and processes can be visualized by fluorescence microscopy (Fig. 2d) (Hedgecock et al. 1985; E. Hedgecock, pers. comm.). In contrast, egl-43 mutants, phasmid neurons often could not be visualized with these dyes (Fig. 2e). Although most egl-43 phasmid neurons failed to fill with DiI, those that took up the dye appeared normal: The cell bodies were in their usual positions, and axonal and den- 


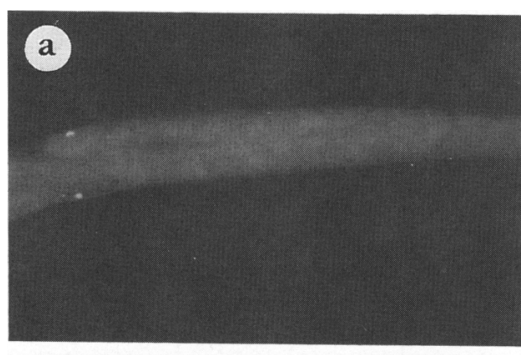

wild type, serotonin
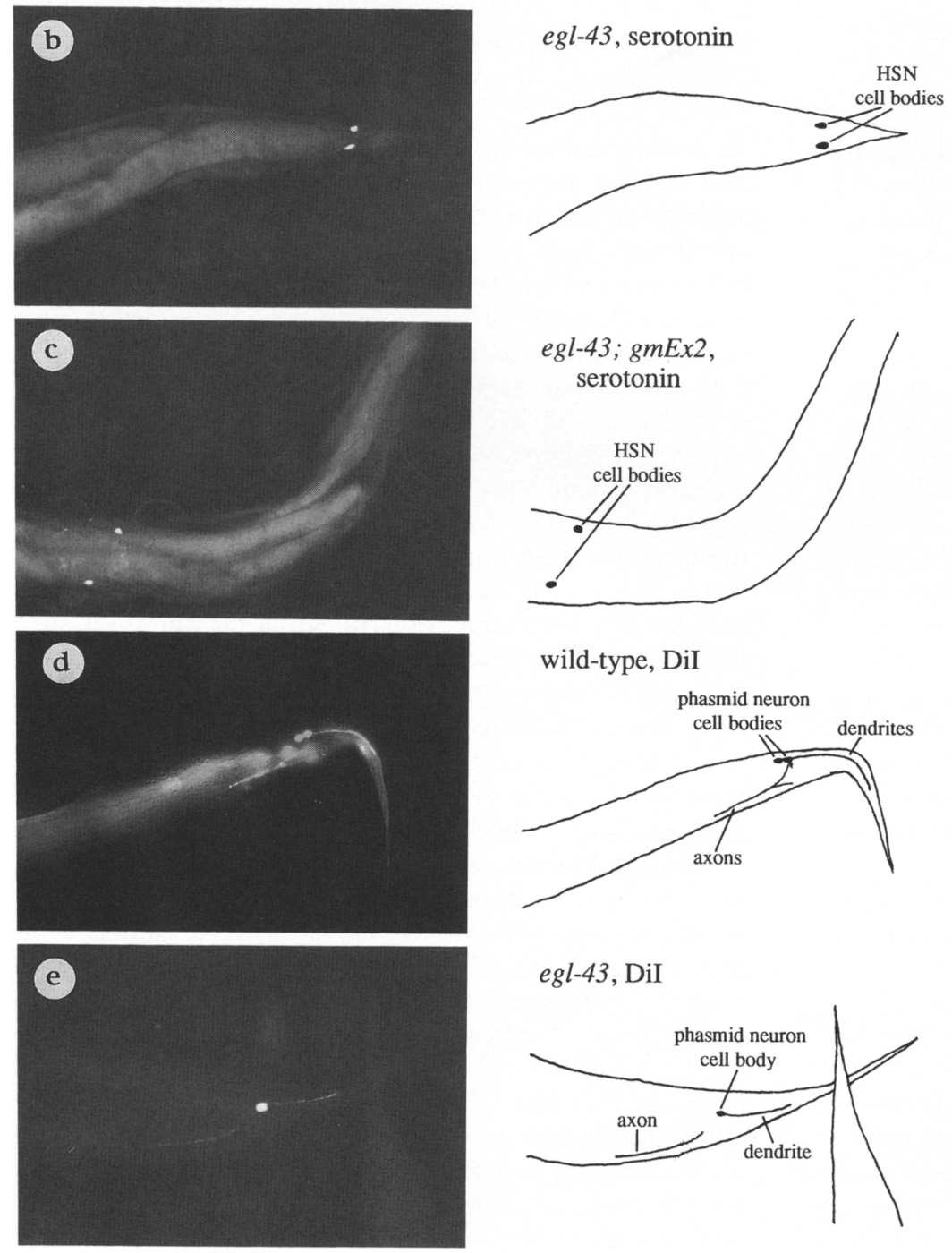

$e g l-43$, DiI

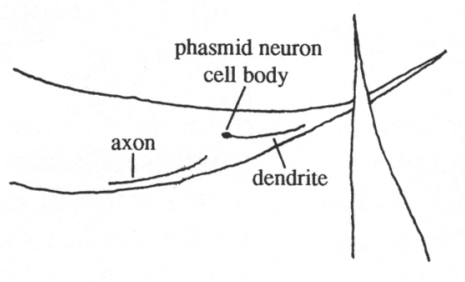

Figure 2. egl-43 mutants are defective in HSN cell migration and in phasmid neuron staining. $(a-e)$ Fluorescence photomicrographs and tracings of wild-type and egl-43 adult hermaphrodites either stained with an anti-serotonin antiserum $(a, b, c)$ or soaked in the fluorescent dye $\operatorname{DiI}(d, e) .(a)$ Ventral view of a wildtype (N2) hermaphrodite stained with an antiserum to serotonin. The bright ovals, which are located near the middle of the animal, are the HSN cell bodies. (b) Ventral view of an egl-43(n1079) hermaphrodite stained with an antiserum to serotonin. The bright ovals, which are located in the tail, are the displaced HSN cell bodies. This animal illustrates the most extreme type of HSN migration defect, in which the HSNs have failed to migrate from the positions in the tail where they were born. $\langle c|$ Ventral view of an egl43(n1079) hermaphrodite carrying the extrachromosomal array gmEx2, after staining with an antiserum to serotonin. The bright ovals are the HSN cell bodies, which are located in their normal positions near the middle of the animal. The HSN migration defect of this egl43 mutant was rescued by the extrachromosomal array $g m E x 2$, which contains a portion of the egl.43 gene (p43BA-RR) that rescues the egl-43 migration defect. (d) Left oblique view of a wild-type hermaphrodite that was soaked in the fluorescent dye DiI. The bright ovals are the cell bodies of the two phasmid neurons. The phasmid neuron dendrites and axons are labeled in the tracing at right. The fluorescence anterior to the phasmid neuron cell bodies is caused by DiI that has been ingested by the worm and retained in the intestinal lumen. (e) Left oblique view of an egl-43(n997) hermaphrodite that was soaked in the fluorescent dye DiI. The single phasmid neuron that took up the dye exhibited normal dendritic and axonal morphology. The portion of the dendrite connected to the cell body is out of the plane of focus. Note that none of the phasmid neurons in the second animal in the field of view took up the dye. In wild-type animals, $99 \%(n=56)$ of phasmid neurons took up DiI ( $n=$ number of animals), whereas in egl43(n997) and egl-43(n1079) mutants, 33\% $(n=47)$ and $30 \%(n=40)$ of phasmid neurons filled with $\mathrm{DiI}$, respectively. In unc4(el20) egl-43(n997)/mnDf28 animals, $31 \%$ $(n=48)$ of the phasmid neurons filled with DiI. dritic processes appeared wild type (Fig. 2e). Electron micrographs of cross sections though the tails of egl43(n997) animals showed that the sensory ciliary structures of PHA and PHB, which are normally exposed to the environment, were variably missing (E. Hartwieg, G. Garriga and H.R. Horvitz, unpubl.). This observation provides a structural basis for the dye-filling defect of the egl-43 mutants.

In contrast to PHA and $\mathrm{PHB}, 12$ sensory neurons lo- cated in the head that also take up Dil (Hedgecock et al. 1985; E. Hedgecock, pers. comm.) appeared normal in egl-43 mutants (data not shown). It is noteworthy that these head sensory neurons are born at the anterior tip of the embryo and migrate posteriorly during embryonic development (Sulston et al. 1983). The wild-type positions of these sensory neurons in egl-43 mutants indicate that they have migrated normally.

The dye-filling deficit of egl-43 mutants might reflect 
a general defect in phasmid neuron development, for example, in the ability of the phasmid neurons to assume their proper identity. Alternatively, this deficit might reflect a more specific defect in dendrite morphogenesis, for example, in the ability of the phasmid neuron dendrites to extend or connect to the phasmid opening. Besides the HSN and phasmid neuron defects, egl-43 males exhibit a reduced efficiency of mating (Desai and Horvitz 1989). We have not determined the cellular basis for this mating defect.

The egl-43 gene does not function globally in cell migration

Although HSN migration is severely defective in egl-43 mutants, all other cell migrations that occur during embryonic and larval development appear normal (see Materials and methods). Moreover, other than the dendritic defects described above for PHA and PHB, we have not observed any abnormalities in process morphology for 16 classes of neurons that were analyzed /see Materials and methods).

To determine whether the specific effects of the two existing egl-43 mutations on HSN but not other cell migrations could be an artifact of having only weak egl-43 alleles, we scored the final positions of migrating cells in animals that lack the egl-43 gene. There are several deficiencies that fail to complement $e g l-43$ as well as flanking genes (Sigurdson et al. 1984; Desai and Horvitz 1989; Miller et al. 1992). Animals homozygous for several of these deficiencies $(m n D f 14, m n D f 22, m n D f 24, m n D f 25$, $m n D f 26, m n D f 28$, and $m n D f 56)$ progress through embryogenesis, hatch, and then arrest development as larvae. Because the homozygous deficiency animals hatch, Nomarski optics can be used to score the positions of the HSNs as well as the positions of other cells that migrate embryonically. Hermaphrodites homozygous for these deficiencies had HSN migration defects similar to those seen in the egl-43 mutants. We analyzed in detail the positions of migrating cells in animals that are homozygous for two of these deficiencies, $m n D f 24$ and $m n D f 28$.

We scored the positions of neurons (ALM, CAN, and HSN) and mesodermal cells (coelomocyte mother cells, intestinal muscle cells, $\mathrm{M}, \mathrm{Zl}$, and $\mathrm{Z} 4$ ) that migrate embryonically in larvae homozygous for the deficiencies $m n D f 24$ and $m n D f 28$ (see Materials and methods). As in egl-43 mutants, only the positions of the HSNs were abnormal in these homozygous deficiency animals. Moreover, the $\mathrm{Q}$ neuroblasts and their descendants, which migrate during the first larval (L1) stage, also migrated normally in animals homozygous for $m n D f 24$ or $m n D f 28$. Unfortunately, these animals did not progress past the Ll stage, so we were unable to determine whether the SM myoblasts and the distal tip cells of the somatic gonad, which migrate later during larval development, migrated normally. Similarly, we could not determine whether later aspects of HSN development were normal in these homozygous deficiency animals because the HSNs do not begin to differentiate until the second
(L2) or third (L3) larval stages (Garriga et al. 1993). Because cells other than the HSNs migrated normally in animals lacking egl-43, the egl-43 gene product is not necessary globally for cell migration. Desai and Horvitz (1989) described a weak Egl phenotype of $m n D f 28 /+$ animals. Using anti-serotonin staining to visualize the HSNs, we showed that $\mathrm{mnDf28} /+$ animals display a weak but significant defect in HSN migration (data not shown). This effect on HSN migration, which is not seen in egl-43/ + animals, may be a consequence of reducing the dosage of $e g 1-43$ by $50 \%$. Alternatively, reducing the dosage of multiple genes may lead to this defect.

\section{The egl-43 gene encodes two transcripts}

To understand better the role of egl-43 in HSN and phasmid neuron development, we have begun a molecular analysis of this gene. The egl-43 gene maps $\sim 0.08$ map units to the right of the unc- 4 gene and is removed by the deficiency $m n D f 28$ but not by the deficiency $m n D f 60$ (Fig. 3a) (Desai and Horvitz 1989; also, this study). The right endpoints of $m n D f 28$ and $m n D f 60$ are located within genomic DNA contained in the two cosmids W02B7 and R53 (Fig. 3b) (Miller et al. 1992; C. Shamus and $M$. Shen, pers. comm.|, thus restricting the physical location of egl-43 to this region. To determine the precise location of $e g l-43$, we used germ-line transformation to rescue the HSN migration, phasmid neuron, and egglaying defects of the egl-43(n1079) mutant (Fire 1986; Mello et al. 1991). Each of the three cosmids, W02B7, R53, and C40F9, rescued the migration defect, placing the egl-43 rescuing activity within the $15 \mathrm{~kb}$ of genomic DNA shared by these cosmids (Fig. $3 \mathrm{~b}$ ). Furthermore, a 5.6-kb BamHI-ApaI fragment (p43BA), which is located between the right endpoints of $m n D f 28$ and $m n D f 60$, contained egl-43-rescuing activity (Fig. 3b,c).

Northern hybridization experiments using the $5.6-\mathrm{kb}$ BamHI-ApaI fragment as a probe demonstrated that this region encodes poly $(\mathrm{A})^{+}$RNAs of $2.5,1.8$, and $1.0 \mathrm{~kb}$ (Fig. 4). Additional Northern hybridization experiments with $\mathrm{T} 7$ transcripts and DNA subclones of the $5.6-\mathrm{kb}$ BamHI-ApaI fragment as probes showed that the 2.5and 1.8-kb RNAs overlap and are transcribed from left to right and that the $1.0-\mathrm{kb}$ RNA is transcribed from right to left (see Materials and methods). Additional germ-line transformation experiments suggested that the 2.5 - and 1.8 -kb transcripts correspond to the egl-43 gene: Removing sequences from the left end of the $5.6-\mathrm{kb}$ BamHI$A p a$ I genomic DNA fragment, including sequences that encode the 1.8- and 2.5-kb transcripts, abolished rescue (Fig. 3c).

To define the structures of the 1.8- and 2.5-kb RNAs, we determined the sequences of genomic DNA from the region and then used oligonucleotides derived from the genomic sequence as primers to amplify cDNAs by the polymerase chain reaction (PCR) (see Materials and methods). These experiments demonstrated that the 2.5and 1.8 -kb transcripts encode 10 and 5 exons, respectively. The five exons of the 1.8 - $\mathrm{kb}$ transcript are iden- 
The C. elegans migration gene egl-43

a

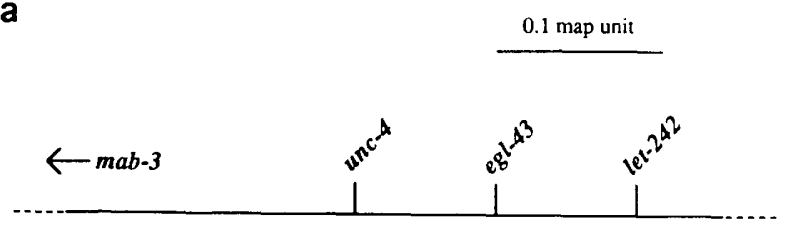

b

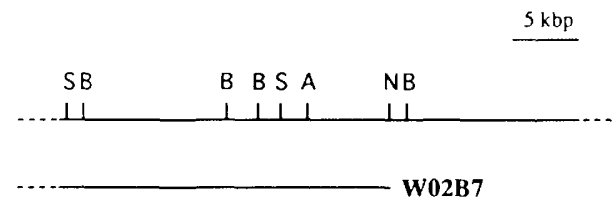

R53

C40F9
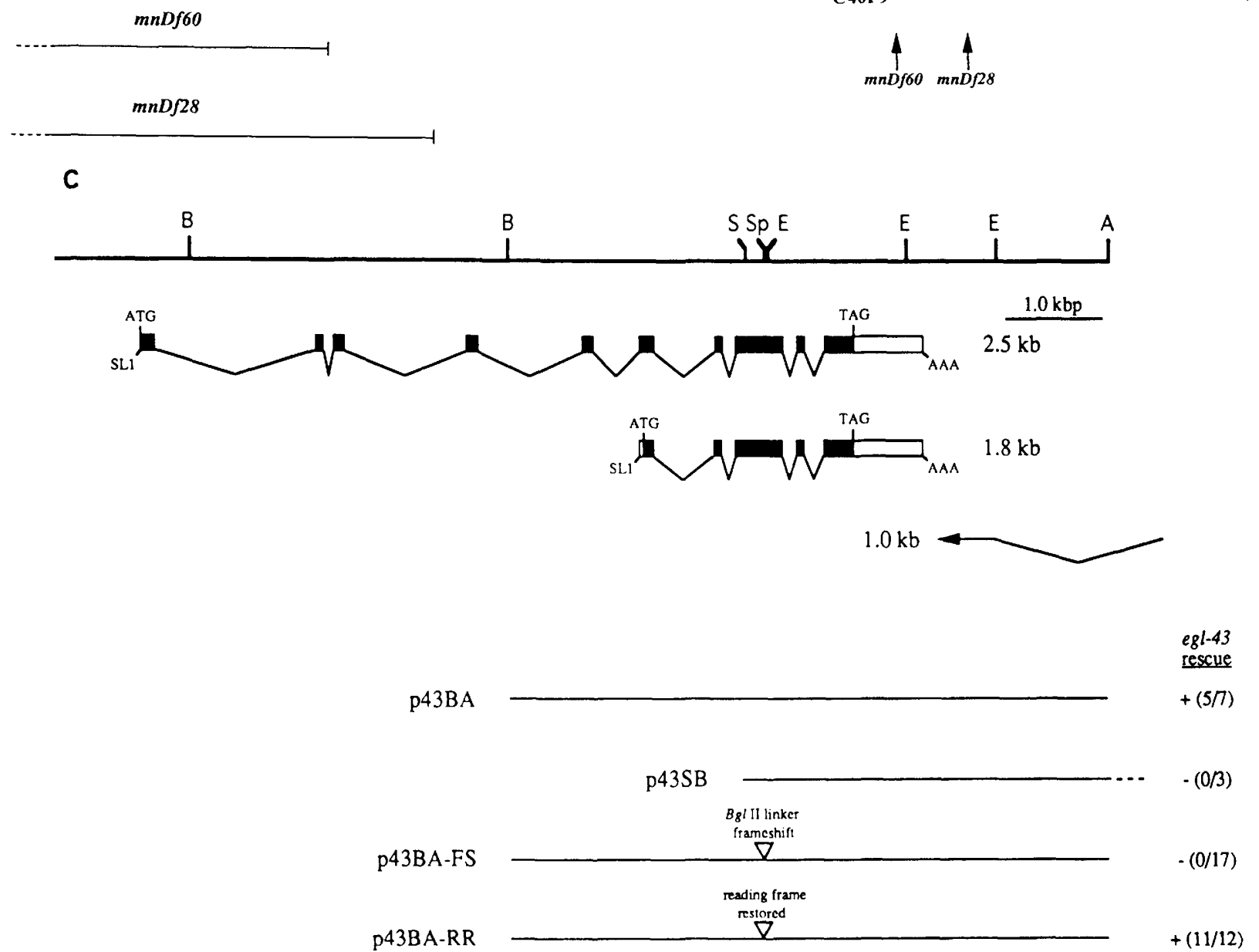

Figure 3. Genetic and physical maps of the egl-43 region of chromosome II. (a) A genetic map of the egl-43 region. The genetically determined extents of the chromosomal deficiencies mnDf28 and mnDf60 are shown below the map. The position of the right endpoint of $m n D f 60$ was previously placed within the egl-43 gene on the basis of its partial complementation of egl-43(n997) (Miller et al. 1992). In our experiments, however, mnDf60 complemented both alleles of egl-43 (see Materials and methods). (b) Physical mapping of the egl-43 gene. The top line represents a restriction map of the genomic DNA contained within the egl-43-rescuing cosmid R53 (data not shown). The three cosmid clones WO2B7, R53, and C40F9 rescued (+) the HSN migration defects of egl-43 mutants when maintained as an extrachromosomal array after germ-line transformation. The fraction of independently derived transformed lines rescued for the HSN migration defect is presented in parentheses for each cosmid clone. The approximate positions of the right endpoints of $m n D f 28$ and $m n D 60$ are indicated by arrows. (c) An expanded restriction map of the egl-43 region, showing the structure of the 2.5-, 1.8-, and 1.0-kb RNAs and subclones that either rescued $(+\mid$ or failed to rescue $(-\mid$ the HSN migration defects of egl-43 mutants when maintained as an extrachromosomal array after germ-line transformation. The fraction of independently derived transformed lines rescued for the HSN migration defect is presented in parentheses for each cosmid clone. (SLl) Trans-spliced SLl leader sequences; (ATG and TAG) the predicted start and stop sites of translation, respectively; (AAA) the site of poly(A) addition. Solid boxes represent coding sequences; open boxes represent untranslated sequences of the 2.5- and 1.8-kb transcripts. Northern hybridization experiments demonstrated that the $1.0-\mathrm{kb}$ RNA is transcribed from right to left, and its $3^{\prime}$ exon(s) is contained within the $0.9-\mathrm{kb}$ EcoRI fragment. Southern hybridization experiments and partial sequencing of a cDNA of the $1.0-\mathrm{kb}$ transcript suggest that the $3^{\prime}$ exon is spliced to sequences to the right of the ApaI site; the precise structure of the $1.0-\mathrm{kb}$ transcript has not been determined. The structures of the plasmids used in the rescue experiments are described in Materials and methods. p43BA-FS is a derivative of p43BA that contains a frameshift mutation in the third exon of the $1.8 \mathrm{~kb}$ transcript. Southern analysis of DNA prepared from five roller lines that had been injected with p43BA-FS showed that all five lines contained injected egl-43 sequences (data not shown). p43BA-RR is a derivative of p43BA-FS that has a restored reading frame. Abbreviations: (A) ApaI; (B) BamHI; (E) EcoRI; (N) NotI; (S) SalI); (Sp) SphI. 


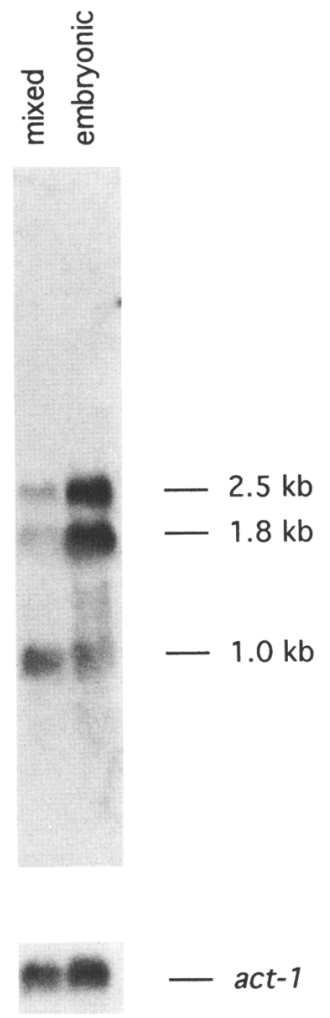

Figure 4. Northern hybridization analysis. A Northern blot of poly $(\mathrm{A})^{+}$RNAs $(10 \mu \mathrm{g} /$ lane) prepared from mixed-stage (left lane) and embryonic (right lane) cultures of the wild-type N2 strain. The Northern blot was probed individually with the egl43-rescuing genomic subclone p43BA (upper blot) and the act1-specific probe $\mathrm{pW}-16-210$ to standardize the amount of RNA loaded into each lane.

tical to the five $3^{\prime}$ terminal exons of the $2.5-\mathrm{kb}$ transcript (Fig. 3c). Amplification of cDNAs with an oligonucleotide complementary to the trans-spliced leader RNA SL1, which is added to the $5^{\prime}$ ends of many C. elegans transcripts (Krause and Hirsh 1987), and second oligonucleotides complementary to internal exon sequences demonstrated that the $5^{\prime}$ ends of both the 2.5 - and $1.8-\mathrm{kb}$ transcripts are generated by trans-splicing to SL1. Both of these $5^{\prime}$ ends were confirmed by primer extension analysis (data not shown). Primer extension analysis also revealed a second $5^{\prime}$ end for the $1.8-\mathrm{kb}$ transcript, starting
40 nucleotides upstream of the $3^{\prime}$ splice site to which SLl is added (C. Guenther, unpubl.). The most likely explanation of this result is that the fifth intron of the $2.5-\mathrm{kb}$ transcript contains a promoter for the $1.8 \mathrm{-kb}$ transcript. The $3^{\prime}$ ends of the $2.5-$ and $1.8-\mathrm{kb}$ transcripts shown in Figure 5 were determined by rapid amplification of cDNA ends (RACE) (see Materials and methods; Frohman et al. 1988).

Although the 5.6-kb BamHI-ApaI-rescuing subclone contains coding sequences for the entire $1.8 \mathrm{-kb}$ transcript, it lacks coding sequences for the $5^{\prime}$ end of the 2.5-kb transcript (Fig. 3c). To determine whether the 1.8or 2.5-kb transcript is responsible for the egl-43-rescuing activity, we inserted a BglII linker into a unique SphI site in p43BA (p43BA-FS). The linker, which added eight nucleotides and created a frameshift in the open reading frame common to both the $1.8-$ and $2.5-\mathrm{kb}$ transcripts, abolished egl-43-rescuing activity. Cutting this construct at the linker BglII site and filling in the end by use of the Klenow fragment of DNA polymerase I restored both the open reading frame and egl-43-rescuing activity for the HSN migration, phasmid neuron, and egg-laying defects (p43BA-RR; Figs. $2 c$ and $3 c$; see Materials and methods). In p43BA-RR, four new amino acids replace a methionine encoded at the Sphl site of p43BA. These results demonstrate that the 1.8 - and/or $2.5-\mathrm{kb}$ transcripts encode the products of the egl-43 gene.

Two results suggest that expression of the $1.8 \mathrm{~kb}$ transcript may be sufficient to rescue the egl-43 phenotypes. First, the 5.6-kb BamHI-ApaI-rescuing subclone lacks coding sequences for the $2.5-\mathrm{kb}$ but not the $1.8 \mathrm{-kb}$ transcript (Fig. 3c). Second, the right endpoint of $m n D f 60$, which complemented the egl-43 alleles and did not cause HSN migration defects when homozygous (see Materials and methods), breaks within a HindIII-BamHI fragment that contains the second, third, and fourth exons of the $2.5-\mathrm{kb}$ transcript (data not shown). Thus, the first and possibly the second, third, and fourth exons of the $2.5 \mathrm{~kb}$ transcript, are missing from the $m n D f 60$ chromosome, supporting the hypothesis that the $1.8-\mathrm{kb}$ transcript is sufficient to rescue the egl-43 phenotype. Our experiments do not address whether the $2.5-\mathrm{kb}$ transcript functions in HSN, PHA, or PHB development.

The two egl-43 transcripts encode distinct zinc finger proteins

Sequence analysis of the egl-43 cDNAs revealed that the

Figure 5. The nucleotide sequence and deduced amino acid sequence encoded by the egl-43 2.5-kb transcript. The sequence of the 2.5-kb transcript, starting with the SLl trans-spliced leader (broken underline) and ending at the poly(A) tract, is shown. The first ATG (amino acid position 1) of the $2.5-\mathrm{kb}$ transcript is shown as the first methionine of the larger protein, although the second methionine at amino acid 68 might represent the initiator methionine. The arrow indicates the proposed initiator methionine of the 1.8 -kb transcript; this methionine is located within the third zinc finger encoded by the $2.5-\mathrm{kb}$ transcript. The $5^{\prime}$ end of the $1.8-\mathrm{kb}$ transcript is apparently generated by splicing of SLl to the $5^{\prime}$ end of the exon containing this methionine (the position of the $5^{\prime}$ of the exon is indicated by the arrowhead immediately upstream). The two highly acidic regions are underlined. Each of the zinc fingers is boxed. The asterisk $\left({ }^{*}\right)$ indicates the position of the TAG amber stop codon. The positions of introns are indicated by arrowheads. A good candidate for the poly(A) ${ }^{+}$addition signal is underlined with a thick line (Proudfoot and Brownlee 1976). The sequences of the two egl-43 cDNAs were determined by sequencing genomic DNA (not shown) and confirming the structure of the transcripts by PCR of cDNAs, RACE, and primer extension (see Materials and methods). 
2.5- and 1.8-kb transcripts could encode proteins of 581 and 360 amino acids, respectively (Fig. 5). The larger Egl43 protein contains six zinc finger motifs of the $\mathrm{C} 2 \mathrm{H} 2$ type (such zinc fingers were first discovered in the $X e$ nopus transcription factor IIIA; Miller et al. 1985) and two acidic regions that could function as transcriptional activators (Ma and Ptashne 1987). The smaller protein contains the 360 carboxy-terminal amino acids of the larger protein, including three of the six zinc finger motifs and one of the acidic regions. The first methionine of

GGTTTAATTACCCAAGTTTGAGGATGAGCATCGACACAGACTTCCTCACGAGTGTTGAGGTAAAGGAGGATGAGCTACATGGAAATGTGC

1 TCATTGCAGTAACTCAAATTGACT $E$ V K E

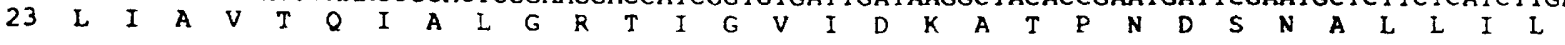

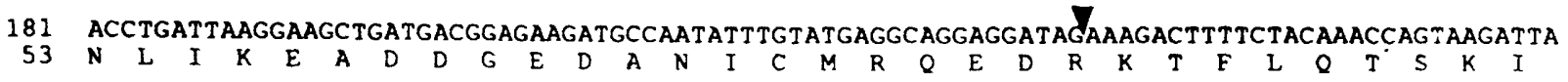

271 TCAATATTGGAGAGCGTCTTCTTCTACAAAGACTGTCCGAAGAGGAGTGTGATGAGGAGGATCAGGATGATCTTGAGAATT:AATTTTGT

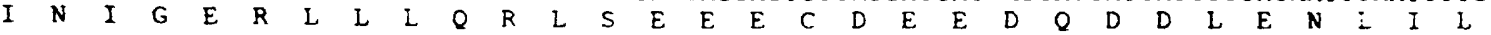

361

TAAAAGATGAAGATCOGCCGgaCAGTACTCAAAGCTGCACAAAGAGCAGCAGTGAAGACAGCAATCTAAACGGTTTCGAGGAGTATATTC

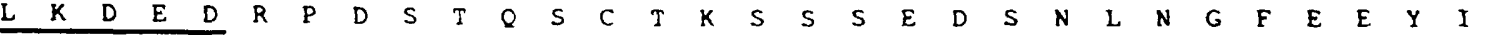

143 GAGAACACGGCGAACTTGTACCTGGTCAAACGCCTCCCGACGGATCACACAAGTGTGGAGTTTGTCCAAAGAGTTTTTCAAG-OCAAGCG

541

173

631

811

GTCTCAAACAACACTCTCATATTCAT TGCTCCT I AAAGCCGT TTCGGTGTCATTTGTGTCCAAAGTCCTACACACAATTCTCEAATCTGT

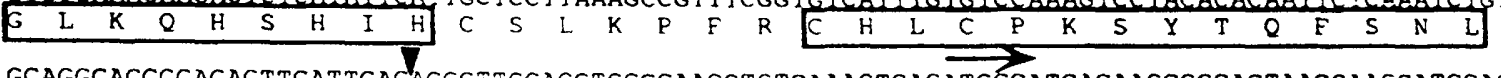
GCAGGCACCGGAGAGTTCATTCAGACGgTTGGACGTGCCCAACGTGTCAAAGTCAGATGECATCACAAGCGGCACTAACGAEGiAATCGAC

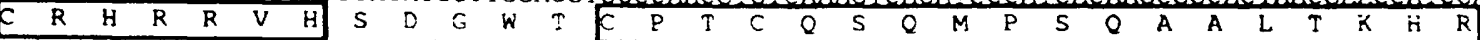
CAGTTTGCGAGATGACTGCACTCTACAAACCAITGATGGCGCAACTTGCCGGATTGAGCGGAGCAGGTGGATTAGGTTCCG:こCCATATT

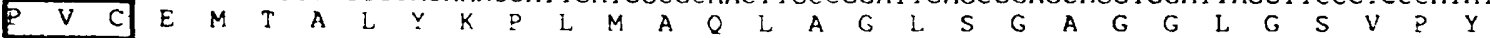

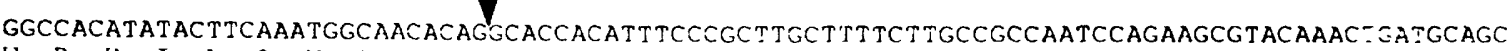

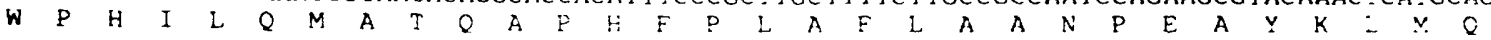
Agacgacgtgtgcatctccagatgccgagteitccadigg

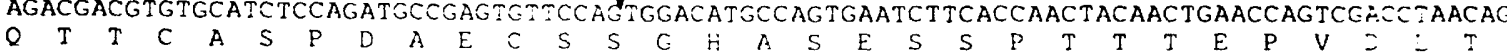
CTACACCAAAACCTCCTTCGACGTCTSAAATGGAAACTACATCAAAGTCCGACGATGGAGAGGATCGTGACAGCATCGGAGR $=: C T G G G A$

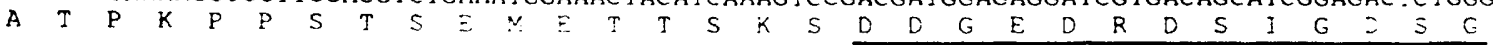
ATGATGATGATGATGACTCAGAACC:GSAETCCIAGATGAGTCGTCCACAACAACGTCAACGAAAAAGCGTCCGACATCTCAOÃAATI

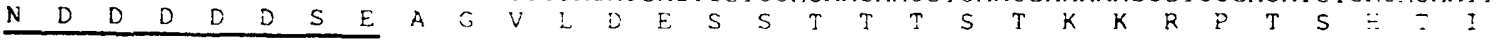
CCGACATACTCGCTGCTCCACAACTCGSTGCTCAGGCTTTGAATCGACGTTCCTTGGCATGCTTCAGCGCTCGCTTAAT:2:-ATCCAG

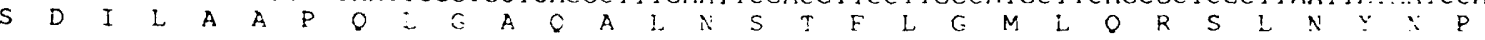

CAGTTCCATCGCCTCACTCATTTCTAHGAGCAA_GHGCGGAGCAAAAGCATCATCATCACCAAGCTCGAGCAGTGGAAGTGG:-:̈GGATA

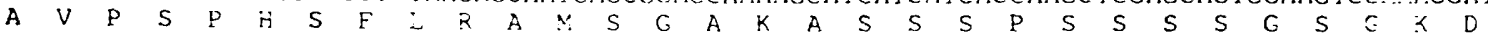

GGT ACACGTGCAAGTCTGTCAGAMA: G TCCAAGATCAGCGAATTTGACAAGACATTTAAGGACACATACAGGAGAGC

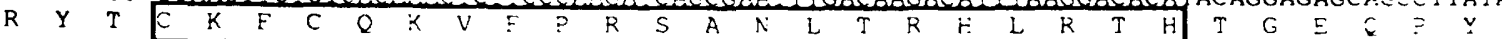

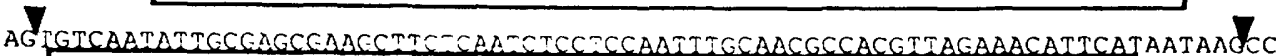
CACCCCACAATCATCATCGTCAACGAAGTCTGCACAATTCAACCTCAACCTCCACTACTACTACTACCGTCCATCATCCTCZ:- :CATC

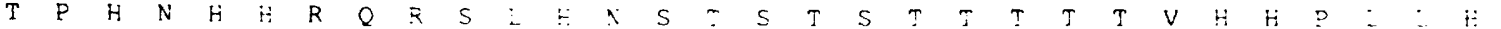

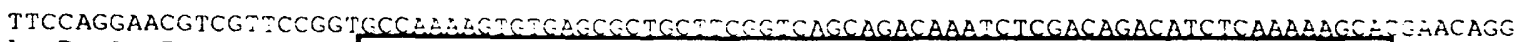

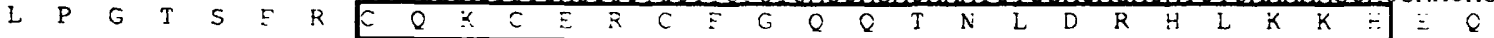

CCGCTGAGCTTCTTCCAGATATTCC@CACCICACE@CCGCAITTATGAAGATTGTCTAGTCTAAATTGTTCTAATTMTC::-: :GAAT

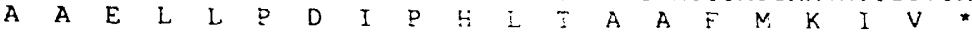

ATTTTTTGGAATCTGATAGATTTAAATTTGATATTCCTAATGGGAATATTAGGAAAGCGGAAATATTGATTAGCCGTAACP.:TT TCCAAAAATAATCACATGTCCCC TCTAGAAACCATTTATTTTTTTTCTAGAATTTTCCAAAACAAAACCGTTCCCTCTTC ¿ここGATCT TCCTCCTGCGATTCTTTCAACTAAACTTTTTGTTTTGTTGTCCCAGGCGCGAAATT T TGCGCCAAAAATACGGTACACGE: $T=C G A C A$ CGGCAAAGTTTTATTGAATTAAAAGGTGTGCGCCTTTAAAGATTACTGTAAGTTAAAACTTTTCTGTGGAATTTTAATTGA:-:TAAAA ATATATTTTATTTTTCAATCACAAT TTCAATCGGAAAAATATGAGAATTCTGAATTACAGTACTCTTTAAATATCGAAAA-こ- $T$ TCGTT CCGAGGCCGGAAACCGTATTTTTAAAGCGAAAACCGAAAAATTTCGCGCCTGGATAATATATTTAATGCTTACATTCTATT:- $C: G T C T$ TCATTGAAAAT TCGAAACACATT TCATTTCTCTCATTTCTTCAAACCAATCGATTGTTGACGGGATTT TCCCCTTCTTTTAG:-_?TCCT TTAAATGTACATACCGTACCAGTGCTCTCTTTGAAATAAACAAGATGTTCTTTAAAAAAAAAAAAAAAA

Figure 5. (See facing page for legend.) 
the $1.8-\mathrm{kb}$ transcript begins within the third zinc finger motif of the larger protein.

The six zinc finger motifs encoded by egl-43 are similar to 6 of the 10 zinc finger motifs encoded by Evi-1, a gene that was originally identified as the site of retroviral insertions that lead to myeloid leukemia in mice (Morishita et al. 1988). The Egl-43 zinc-finger motifs $1-6$ correspond to the zinc finger motifs 5-10 of the murine Evi-1 protein (Fig. 6). Both the order and sequences of the Egl-43 and Evi-1 zinc finger motifs are conserved; and as in the murine gene, the zinc finger motifs of Egl-43 are clustered into two domains. The Egl-43 and Evi-1 zincfinger motifs of the second domain are more highly conserved (67 of the 84 amino acids are identical) than those of the first (45 of the 85 amino acids are identical) (Fig. $6 \mathrm{~b})$. The third Egl-43 zinc finger, which is the least conserved of the zinc fingers, also contains the presumptive initiator methionine of the smaller 360-amino-acid Egl43 protein; this methionine replaces a conserved phenylalanine found in most zinc fingers of this class (Fig. 6b). There are differences, however, in both the number and arrangement of zinc fingers motifs between Evi-1 and Egl-43; only three of the seven Evi-1 zinc fingers of the first domain are present in Egl-43, and the 47 amino acids that separate the fifth and sixth zinc fingers of Egl-43 are absent in Evi-1 on the basis of sequenced cDNAs (Fig. $6 a)$. Outside the zinc finger motifs there is no obvious similarity between the Evi-1 and Egl-43 protein sequences.

\section{Discussion}

The C. elegans gene egl-43 plays a key role in the migra- tions of the HSNs and also functions in the development of the PHA and PHB sensory neurons. Our genetic results argue that egl-43 functions specifically in HSN migration rather than globally in cell migration: Animals homozygous for egl-43 mutations or deficiencies that span egl-43 are defective in HSN migration but normal for all other long-range cell migrations. egl-43, however, might also function in the outgrowth of the PHA and PHB dendrites (see Results). This possibility is noteworthy, because cell migration and nerve process outgrowth are phenomenologically and mechanistically similar, requiring similar cytoskeletal elements as well as similar cell surface and extracellular matrix proteins (Singer and Kupfer 1986; Reichardt and Tomaselli 1991). The specificity of egl-43 activity for HSN and phasmid neuron development differs from the pleiotropic activity of most cell migration and axonal outgrowth genes that have been identified in C. elegans, which function in the migrations of many cells and axons (Hedgecock et al. 1985,1987,1990; Desai et al. 1988; Manser and Wood 1990; Siddiqui and Culotti 1991; McIntire et al. 1992). Such genes define components that function more generally in cell migration and process outgrowth than does egl-43. Our molecular analysis indicates that egl-43 encodes two proteins that contain zinc finger motifs, suggesting that egl-43 controls HSN migration indirectly, by transcriptionally regulating other genes.

Genetic analysis in $C$. elegans has revealed several other genes that appear to function as transcriptional regulators in the control of cell migration. The C. elegans genes lin-39, mab-5, and egl-5 encode proteins that contain homeo domains and appear to specify positional information in C. elegans (Kenyon 1986; Costa et al. b

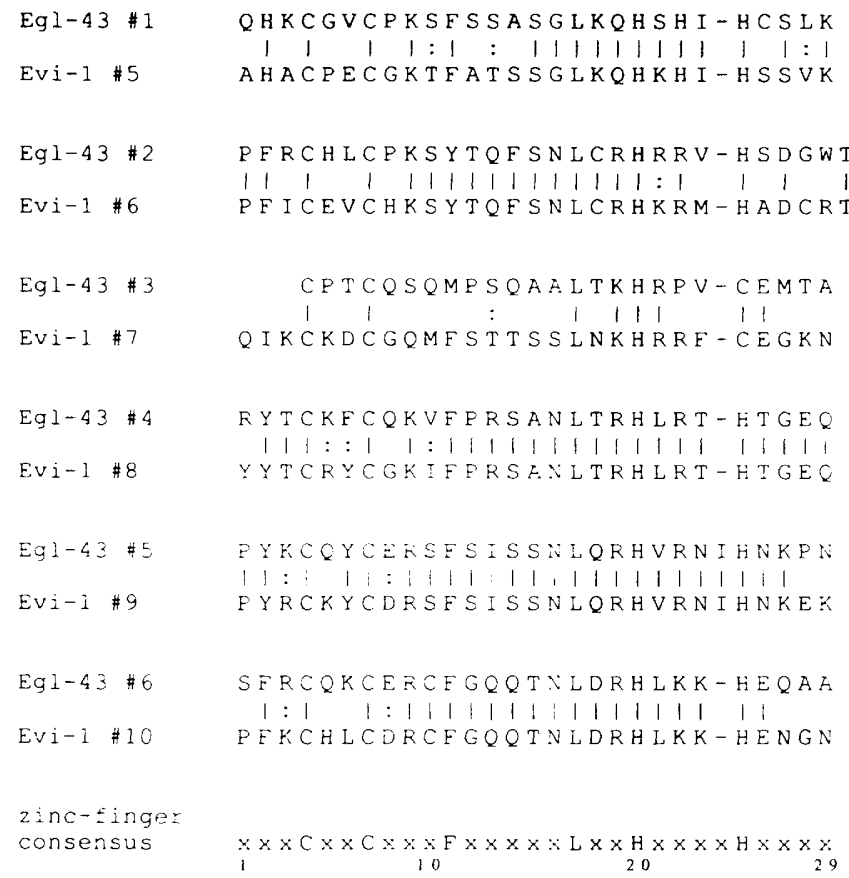

\begin{tabular}{|c|c|}
\hline Evi-1 \#5 & 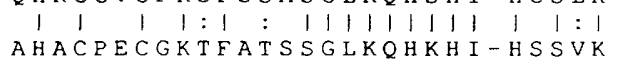 \\
\hline $\begin{array}{l}\text { Eg } 1-43 \# 2 \\
\text { Evi-1 \#6 }\end{array}$ & 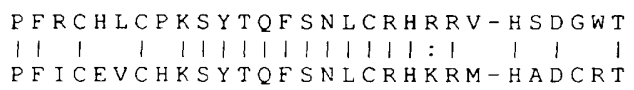 \\
\hline $\begin{array}{l}\text { Egl- } 43 \# 3 \\
\text { Evi-1 \#7 }\end{array}$ & 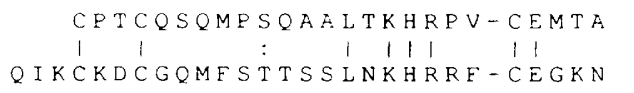 \\
\hline $\begin{array}{l}\text { Eg } 1-43 \# 4 \\
\text { Evi-1 \#8 }\end{array}$ & 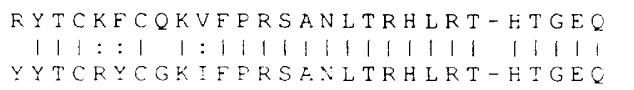 \\
\hline $\begin{array}{l}\text { Eg } 1-43 \# 5 \\
\text { Evi-i \#9 }\end{array}$ & 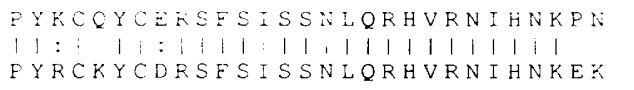 \\
\hline $\begin{array}{l}\text { Egl-43 \#6 } \\
\text { Evi-i } \# 10\end{array}$ & 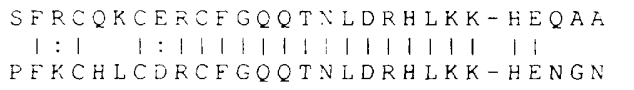 \\
\hline $\begin{array}{l}\text { zinc-inge: } \\
\text { consensus }\end{array}$ & $\underset{1}{X \times X \times \times C \times \times \underset{10}{X F} \times \times \times \times \times L \times \underset{20}{H} \times \times \times \times H \times \times \times \times}$ \\
\hline
\end{tabular}

a

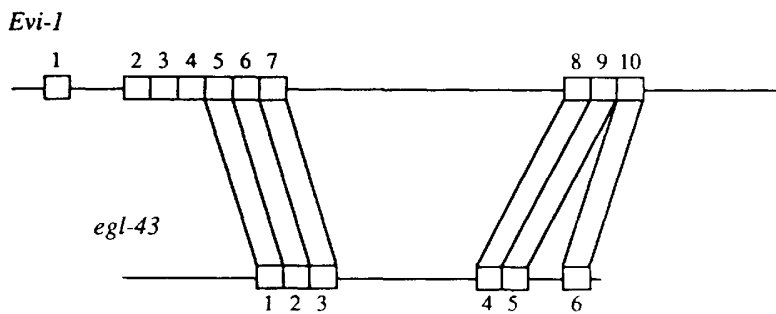

Figure 6. Comparison of the C. elegans egl-43 and murine Evi-1 genes. (a) The orders of the Evi-1- and egl-43-related zinc fingers are similar. The lengths and structures of the murine Evi-1 and the $C$. elegans egl-43 cDNAs are represented. The positions of the zinc fingers are indicated by boxes. The Evi-1 transcript encodes 10 zinc fingers in two clusters (1-7 and 8-10), whereas the egl-43 transcript encodes 6 zinc fingers in two clusters $(1-3$ and 4-6). Zinc fingers 5-7 of $E v i-1$ are similar in sequence to zinc fingers 1-3 of egl-43, and zinc fingers 8-10 of Evi-1 are similar in sequence to zinc fingers $4-6$ of egl-43. (b) Sequence comparisons between the zinc fingers of Evi-1 and egl-43. Vertical dashes indicate identical amino acids; dots indicate conserved amino acids. 
1988; Chisholm 1991; Clark et al. 1993; Wang et al. 1993). All three of these genes are required for cell migrations in C. elegans: lin-39 for the migrations of the QR neuroblast, egl-5 for the migrations of the HSNs and the QL neuroblast, and mab-5 for the migrations of the QL neuroblast and the male sex myoblasts /Chalfie et al. 1983; Kenyon 1986; Desai et al. 1988; Desai and Horvitz 1989; Salser and Kenyon 1992; Clark et al. 1993; Wang et al. 1993). By analogy to these genes, egl-43 might function in the control of positional information during the development of the HSNs and phasmid neurons, which are generated near one another. Most other cells in the tails of egl-43 mutants, however, appear normal. Thus, eg1-43 mutations appear to be more specific in their effects than are $e g l-5$, lin-39, and mab-5 mutations, which result in multiple cell fate transformations. The egl-5, lin-39, and mab-5 genes function autonomously in their regulation of migrating cells. We do not know whether egl-43 functions autonomously or nonautonomously in HSNs and phasmid neuron development.

The similar order and sequence of the C. elegans Egl43 and murine Evi-1 zinc finger motifs suggest that these genes share a common evolutionary origin. The Evi-1 gene encodes a $145-\mathrm{kD}$ nuclear protein (Matsugi et al. $1990)$ that binds DNA in a sequence-specific manner (Perkins et al. 1991a; Delwel et al. 1993), consistent with a role in transcriptional regulation. The crystal structure of a complex containing the zinc fingers from the mouse immediate early protein Zif 268 and its consensus DNAbinding site reveals that amino acids within and adjacent to the $\alpha$-helical regions of the zinc fingers (positions 14 26 of the consensus zinc fingers in Fig. 6b) define their binding specificity by making direct contact with the DNA (Pavletich and Pabo 1991). These presumptive $\alpha$-helical regions of the zinc finger motifs of the C. elegans Egl-43 and murine Evi-1 proteins are particularly well conserved. Within this region, the amino acids of the three zinc fingers from the second domains of Egl-43 and Evi-1 are identical, suggesting that they might bind to similar DNA sequences.

The Evi-1 gene was identified originally as the site of retroviral insertions that lead to murine myeloid leukemia (Morishita et al. 1988). More recently, rearrangements of the cognate human gene (EVI1) have been associated with cases of human acute myelogenous leukemia (Morishita et al. 1992). Because Evi-1 expression is detectable in transformed but not normal myeloid cells, leukemia presumably results from ectopic Evi-1 expression (Morishita et al. 1988). Although the normal role of Evi-1 in the mouse is not known, the expression patterns of its transcripts during murine development have been studied (Perkins et al. 1991b). In the context of our results, it is noteworthy that some cells express Evi-1 as they migrate. For example, cells of the developing vomeromedial organ of Jacobson, an additional taste sensor in rodents, transiently express Evi-1 as they invade the underlying mesenchyme (Perkins et al. 199lb).

If the Egl-43 proteins do function in transcriptional control, what genes do they regulate? Presumably they regulate, either directly or indirectly, genes that function in the process of cell migration. Thus, it seems likely that the egl-43 transcriptional targets might be found in the remaining 18 genes known to function in HSN migration.

\section{Materials and methods}

\section{Strains and genetics}

Strains were grown at $20^{\circ} \mathrm{C}$ and maintained as described by Brenner (1974). This paper uses standard C. elegans genetic nomenclature (Horvitz et al. 1979).

In addition to the standard wild-type strain (N2), strains of the following genotypes were used in this work: egl-43(n997), egl43(n1079), $m n D f 14 / m n C 1, m n D f 24 / m n C 1, m n D f 25 / m n C 1$, $m n D f 26 / m n C 1, m n D f 28 / m n C 1, m n D f 56 / m n C 1$, and $m n D f 60 /$ $m n C 1$. The isolation and initial characterization of the two egI-43 alleles $n 997$ and $n 1079$ were described by Desai and Horvitz (1989) and by Desai et al. (1988). The LG II deficiencies are described by Sigurdson et al. (1984). We observed that mnDf60 complements the egg-laying and HSN migration defects of egl43(n997) and egl-43(n1079) mutants; this result differs from the partial complementation described by Miller et al. (1992). $\mathrm{mnC1}$ is a LG II balancer that contains the mutations $d p y$ 10(e128) and unc-52(e444) (Herman 1978).

The strains $m n D f 24 / m n C 1$ and $m n D f 60 / m n C 1$ segregated $\sim 50 \%$ wild-type animals (mnDf/mnC1), $25 \%$ sterile Dpy Unc animals $(m n C 1 / m n C 1)$, and $25 \%$ arrested larvae $(m n D f / m n D f)$. In contrast, $m n D f 28 / m n C 1$ animals not only segregated arrested larvae but many dead eggs. The embryonic lethality seen in this strain is surprising, because genetically $m n D f 28$ behaves like a smaller deficiency than mnDf24 (Sigurdson et al. 1984). Moreover, the $m n C 1$ balancer chromosome in this strain breaks down generating Unc non-Dpy and Dpy non-Unc animals. These results suggest that $m n C 1$ is abnormal in this strain and/ or that $m n D f 28$ is not a simple deficiency.

Neither of the two deficiencies that remove egl-43 nor the egl-43 mutants exhibit maternal rescue: Homozygous deficiency or egl-43 mutant animals of heterozygous mothers display an HSN migration defect.

\section{Analysis of cell migrations}

All long-range migrations were determined to be normal or defective on the basis of the final positions of the migrating cells as observed using Nomarski optics. For each genotype the position of each cell was scored in at least 10 animals. The final positions of cells that migrate during embryonic development were determined in newly hatched first larval (L1) stage animals; these migrations are described by Sulston et al. (1983).

The Q neuroblasts and their descendants, as well as the sex myoblasts (SMs) and the distal tip cells (dtcs) migrate during postembryonic development (Sulston and Horvitz 1977; Kimble and Hirsh 1979). The final positions of the left and right $Q$ descendants were scored in late $\mathrm{Ll}$ animals. The final positions of the SMs were scored in third larval (L3) stage animals. In the male the SMs and their progeny migrate posteriorly to various positions in the tail. Because the diagonal muscles, which are derived from the SMs in males, appeared normal in egl-43 mutants, we inferred that the male SMs migrated normally. The pathways taken by the dtcs during their migrations was inferred from the shape of the gonad in late L4 hermaphrodites (Kimble and Hirsh 1979).

In animals homozygous for the two egl-43 mutations $n 997$ 
and $n 1079$ and the two deficiencies $m n D f 24$ and $m n D f 28$, only the HSNs were misplaced; all other migrating embryonic cells and the descendants of the QL neuroblasts were in their normal positions. The HSNs were similarly displaced in the egl-43 mutants and the homozygous deficiency animals. In animals homozygous for the deficiency $m n D f 60$, which complements the egl-43 mutations, all embryonic migrating cells, including the HSNs, and the descendants of the QL neuroblasts were in their normal positions. The average positions of the HSNs were scored in $>10$ animals for the egl-43 mutants and mnDf24 homozygotes using the method described by Desai et al. (1988). When normalized to the positions of the HSNs in wild-type animals $(100 \%$ migration; $n=48)$, the average HSN position was $5 \%(n=158)$ for egl-43(n997)/egl-43(n997) animals, $10 \%$ $(n=136)$ for egl-43(n1079)/egl-43(n1079) animals, and $9 \%$ $(n=71)$ for $m n D f 24 / m n D f 24$ animals. We were unable to score the migrations of the SMs and the dtcs in animals homozygous for $m n D f 24, m n D f 28$ and $m n D f 60$, because these migrations occur after the stage (L1) in which the homozygous deficiency animals arrest development.

Homozygous deficiency animals were generated by allowing $m n D f 24 / m n C 1, m n D f 28 / m n C 1$, or $m n D f 60 / m n C 1$ adult hermaphrodites to lay eggs for $1-2 \mathrm{hr}$ and then removing the adults. After $24-36 \mathrm{hr}$ the arrested Lls on the plate were scored for cell migration defects.

The positions of the SMs and the dtcs in the two egl-43 alleles and of all migrating cells in egl-43(n997)/mnDf28 animals were normal. To score egl-43(n997)/mnDf28 animals, unc-4(e120) egl-43(n997)/ + + males were crossed with $m n D f 28 / m n C 1$ hermaphrodites, and the Unc-4 cross progeny [unc-4(e120) egl$43(n 997) / m n D f 28]$ were scored for cell migration defects. unc4(e120) egl-43(n997) animals were also normal for all cell migrations except the migrations of the HSNs.

\section{Indirect immunofluorescence histochemistry and filling sensory neurons with DiI}

Indirect immunofluorescence histochemistry to stain animals for serotonin was performed using the procedure described by Garriga et al. (1993). Rabbit anti-serotonin antisenum was from J. Steinbusch (Free University, Amsterdam, The Netherlands). FITC-conjugated goat anti-rabbit antiserum was from Cappel, Inc. The cell bodies and axons of the non-HSN serotonergic neurons (ADF, NSM, and RIH neurons in hermaphrodites and males, and the serotonergic $\mathrm{CP}$ neurons in males) appeared nor$\mathrm{mal}$ in egl-43 animals.

The egl-43 mutants were also scored for defects in axonal outgrowth by staining animals with an antiserum to the neurotransmitter GABA (McIntire et al. 1992). Rabbit anti-GABA antiserum was from I. Steinbusch. The cell bodies and axons of all six classes of GABA-ergic neurons (McIntire et al. 1993) appeared normal in egl-43 hermaphrodites.

The amphid (sensory neurons in the head) and phasmid (sensory neurons in the tail) neurons were filled with the fluorescent dye DiI using a modification of the procedure developed by Hedgecock et al. (1985). Both classes of phasmid neurons (PHA and $\mathrm{PHB}$ ) and 6 of the 12 classes of amphid neurons (ADL, ASH, ASI, ASI, ASK, and AWB) take up DiI (E. Hedgecock; C. Bargmann, both pers. comm.). Only the PHA and PHB neurons appeared abnormal in egl-43 mutants.

\section{Germ-line transformation}

Germ-line transformation (Mello et al. 1991) was achieved by coinjecting the DNA to be tested $(20 \mu \mathrm{g} / \mathrm{ml})$ and the plasmid
pRF4 $(50 \mu \mathrm{g} / \mathrm{ml})$, which contains the dominant rol-6(su1006) roller marker, into the gonads of young adult egl-43(n1079) hermaphrodites. Transgenic animals typically carry such coinjected DNAs as an extrachromosomal array and are identified by the roller phenotype conferred by pRF4 (Mello et al. 1991). Although egl-43/n1079) animals exhibit defects in egg laying HSN migration, and phasmid neuron development, only the HSN migration defect is fully penetrant; the HSNs are never in their normal positions in egl-43(n1079) mutants (G. Garriga, unpubl.). Because rescue of the HSN migration defect is the most sensitive and unambiguous assay for egl-43 rescue, we defined an egl-43-rescued population as a roller line (derived from an $\mathrm{F} 2$ roller) in which $>20 \%$ of the HSNs were in wildtype positions. The positions of the HSNs were determined in L4 hermaphrodites using Nomarski optics (Desai et al. 1988). If a roller line appeared to be partially rescued /the HSNs occasionally migrated $50-80 \%$ of the distance traveled by wild-type HSNs, which rarely occurs in egl-43 mutants), the positions of the HSNs were determined by staining the lines with anti-serotonin antisera. In addition, some of the lines were scored for rescue of the egg-laying (Egl) and phasmid neuron defects. Ninety percent of egl-43(n1079) hermaphrodites are Egl, and roller lines that were $<40 \% \mathrm{Egl}$ were considered to be rescued for the Egl defect. Wild-type animals almost always have two phasmid neurons per side that take up the dye $\mathrm{DiI}$; in egl$43(n 1079)$ animals, only $10 \%$ of the sides had two phasmid neurons that filled with Dil (data not shown). When tested roller lines with $>40 \%$ of the sides containing two phasmid neurons that filled with DiI were considered to be rescued for the phasmid neuron defect. Roller lines containing p43BA, p43BA-FS, and p43BA-RR were assayed for rescue of the Egl and phasmid neuron defects. By use of the above criteria for rescue, lines containing $\mathrm{p} 43 \mathrm{BA}$ and $\mathrm{p} 43 \mathrm{BA}-\mathrm{RR}$ were rescued for these defects, and lines containing p43BA-FS were not. In these experiments, the lines rescued for the HSN migration were also rescued for the egg-laying and phasmid neuron defects /see Fig. $3 \mathrm{c}$ for the number of lines rescued for the HSN migration, PHA and PHB dye-filling, and egg-laying defects).

In our first germ-line transformation experiments, we used cosmid DNA. To refine the position of egl-43, we used plasmids containing DNA subcloned from the cosmid R53 into pBluescript KS -. The structures of the subclones are illustrated in Figure 3c.

p43BA-FS contains a $B g I I I$ linker ligated into the SphI site of p43BA. The BglII linker added eight nucleotides and created a frameshift mutation; the methionine at position 403 in Figure 5 was changed to glutamate followed by 20 amino acids and an ochre stop codon, which is upstream of zinc fingers 4-6.

To verify that the lack of egl-43-transforming activity of p43BA-FS was caused by the frameshift mutation, we constructed p43BA-RR by digestion of p43BA-FS with BgIII and filling in the $5^{\prime}$ overhang using the Klenow fragment of DNA polymerase I (New England Biolabs) according to the procedure described by Sambrook et al. (1989). p43BA-RR lacks the BgIII site, and DNA sequencing confirmed that the reading frame had been restored, replacing an original methionine by four different amino acids. The restoration of egl-43-rescuing activity in p43BA-RR indicated that the lack of rescuing activity in p43BAFS was caused by the frameshift mutation.

Both egl-43 alleles contain a similar 0.5-kb deletion located at the right end of the $5.6-\mathrm{kb}$ BamHI-ApaI fragment between the EcoRI site closest to the ApaI site in Figure $3 \mathrm{c}$ and the ApaI site, a region that lacks detectable transcripts on Northern blots (data not shown). It seems unlikely that these deletions cause the egl-43 phenotypes by affecting the $1.0-\mathrm{kb}$ transcript, because deleting the region containing the $1.0-\mathrm{kb}$ transcript from $\mathrm{p} 43 \mathrm{BA}$ 
did not abolish rescuing activity (data not shown). In addition, the 2.5-, 1.8-, and 1.0-kb transcript levels appeared normal in RNA prepared from egl-43(n997) embryos (data not shown). Thus, we do not know whether the deletion is the egl-43 mutation and affects the expression of the $2.5-$ and $/$ or $1.8-\mathrm{kb}$ transcripts or a polymorphism that was present in the original strain from which the two egl-43 alleles were derived.

\section{Northern blot hybridization}

C. elegans was grown in liquid culture as described by Meyer and Casson (1986), and poly(A) ${ }^{+}$RNA was isolated as described by Nonet and Meyer (1991). Electrophoresis, blotting, and probing of the RNA was as described by Sambrook et al. (1989). The DNA probes used in these experiments were p43BA / which recognizes the 2.5-, 1.8-, and 1.0-kb transcripts), p43BE (which contains sequences from the $B a m H I$ site to the nearest EcoRI site of $\mathrm{p} 43 \mathrm{BA}$ and hybridized to the $2.5-$ and $1.8-\mathrm{kb}$ transcripts $1, \mathrm{p} 43 \mathrm{E} 2$ (which contains the $0.9-\mathrm{kb}$ EcoRI fragment of p43BA and hybridized strongly to the $1.0-\mathrm{kb}$ transcript and weakly to the 2.5 and 1.8 -kb transcripts), and p43EA (which contains sequences from the EcoRI site to the ApaI site of p43BA and did not hybridize to any transcripts) (see Fig. 3c). The RNA probes were generated using either T3 or T7 RNA polymerase (Sambrook et al. 1989). Digestion of p43BA with SalI and transcription with $\mathrm{T} 7$ polymerase generated a transcript that hybridized to the 2.5 and $1.8-\mathrm{kb}$ transcripts. Digestion of p43BA with SmaI, which cuts between the EcoRI and ApaI sites, and transcription with $\mathrm{T} 3$ polymerase generated a transcript that recognized the $1.0-\mathrm{kb}$ transcript.

\section{DNA sequencing}

Deletions of clones used for sequencing were prepared using exonuclease III and S1 nuclease as described by Sambrook et al. (1989). The sequences of both strands of the DNA were determined by use of Sequenase 2.0 (U.S. Biochemical) according to the instructions provided by the manufacturer.

\section{PCR of $c D N A s$ and $3^{\prime}$ RACE}

Residual genomic DNA present in poly $(\mathrm{A})^{+}$RNA preparations was digested before cDNA synthesis in $100 \mu \mathrm{l}$ of a solution containing $40 \mathrm{~mm}$ Tris $\mathrm{HCl}$ (pH 7.9), $10 \mathrm{~mm} \mathrm{NaCl}, 6 \mathrm{~mm} \mathrm{MgCl}_{2}$, $0.1 \mathrm{mM} \mathrm{CaCl}_{2}$, and 5 units of RQ1 DNase (Promega Biotech) at $37^{\circ} \mathrm{C}$ for $30 \mathrm{~min}$. The RNA was extracted with phenol-chloroform twice and precipitated with ethanol. Complementary DNA was prepared by incubating $25 \mathrm{ng}$ of DNA-free poly(A) ${ }^{+}$ RNA in $20 \mu \mathrm{l}$ of a solution containing $0.2 \mu \mathrm{M}$ p $(\mathrm{dN})^{6}$ (Pharmacia), $50 \mathrm{~mm}$ Tris $\mathrm{HCl}$ (pH 8.3), $75 \mathrm{mM} \mathrm{KCl}, 3 \mathrm{~mm} \mathrm{MgCl} 2,1 \mathrm{mM}$ dNTPs, 20 units of RNasin (Promega Biotech), and 200 units of $M-M L V$ reverse transcriptase (BRL Gibco). The reaction was incubated at $4^{\circ} \mathrm{C}$ for $5 \mathrm{~min}, 22^{\circ} \mathrm{C}$ for $10 \mathrm{~min}, 37^{\circ} \mathrm{C}$ for $60 \mathrm{~min}$, and $95^{\circ} \mathrm{C}$ for $10 \mathrm{~min}$.

cDNAs were amplified in $100 \mu \mathrm{l}$ of a solution that contained the cDNA mixture described above, $10 \mathrm{mM}$ Tris $\mathrm{HCl} / \mathrm{pH} 9.0$ at $25^{\circ} \mathrm{C}$ ), $50 \mathrm{~mm} \mathrm{KCl}, 0.1 \%$ Triton X-100, $25 \mu \mathrm{M}$ primer 1 (see appended list of primers), $25 \mu \mathrm{M}$ primer 2, and 3 units of Taq DNA polymerase (Promega Biotech). The mixture was denatured for $5 \mathrm{~min}$ at $94^{\circ} \mathrm{C}$, followed by 35 cycles of 1 -min denaturation at $94^{\circ} \mathrm{C}, 1-\mathrm{min}$ annealing at $55^{\circ} \mathrm{C}$, and 3 -min extension at $72^{\circ} \mathrm{C}$. The reaction ended with an additional 10 -min extension at $72^{\circ} \mathrm{C}$. The PCR products were cloned in to the EcoRV site of pBluescript $\mathrm{KS}-$, and their DNA sequences were determined.

The $3^{\prime}$ ends of the 2.5- and 1.8-kb transcripts were cloned by use of a variation of the $3^{\prime}$ RACE method described by Frohman et al. (1988). mRNA was incubated with reverse transcriptase, and the $\mathrm{dT}^{17}$ adaptor primer was used in place of the random primer $\mathrm{p}(\mathrm{dN})^{6}$. The $3^{\prime}$ ends were PCR-amplified as described above with the $\mathrm{Eg} 5$ and adaptor primers. The PCR products were cloned into the EcoRV site of pBluescript $\mathrm{KS}-$, and positive clones were identified by probing colony lifts with the 5.6$\mathrm{kb}$ BamHI-ApaI fragment body labeled with $\left[\alpha^{-32} \mathrm{P}\right] \mathrm{dCTP}$ using random oligonucleotides as primers (Sambrook et al. 1989). The sequence of the RACE product mapped the position of the $3^{\prime}$ ends of the 2.5- and 1.8-kb transcripts to the position shown in Figure 5. Table 1 shows a list of oligonucleotides used as primers. Table 2 shows the primer combinations used in the PCR experiments to determine the structures of the egl-43 2.5- and $1.8-\mathrm{kb}$ transcripts.

\section{Primer extension analysis}

The oligonucleotide (Kpe2) used to map the 5 ' ends of the 2.5-

Table 1. Oligonucleotides used to determine the structure of egl-43 2.5- and 1.8-kb transcripts

\begin{tabular}{|c|c|c|c|}
\hline Name & Sequence & Start $^{a}$ & End $^{a}$ \\
\hline Adaptor & 5'-GACTCGAGTCGACATCG-3' & & \\
\hline $\mathrm{Eg} 2$ & 5'-GCATCGACACAGACTTCC-3' & 28 & 45 \\
\hline Eg5 & 5'-CGGTCAGCAGACAAATC-3' & 1664 & 1680 \\
\hline E4 & 5'-GTTATCAATCTCCGTCT-3' & \multicolumn{2}{|c|}{ within fifth intron ${ }^{\mathrm{b}}$} \\
\hline E10 & 5'-GGTGAAGA TTCACTGGC-3' & 96 & 945 \\
\hline Ell & $5^{\prime}$-GCGCTGAAGCATGCCAA-3' & 1241 & 1225 \\
\hline E12 & 5'-CGGTTTTGTTTTGGAAA- 3 & 1962 & 1946 \\
\hline E30 & 5'-CGACATACTCGCTGCTC-3' & 1172 & 1188 \\
\hline E31 & 5'-ATGAATATGAGAGTGTTGTTTGAGAC-3' & 566 & 541 \\
\hline Kpe2 & $5^{\prime} \cdot$ GTGCCGCTTGTGATGGCATCTGAC-3' & 705 & 682 \\
\hline SL1 & $5^{\prime}$-TCTAGAATTCCGCGGTTTAATTACCCAAGTTTG-3' & -13 & 20 \\
\hline $\mathrm{dT}^{17}$ adaptor & $5^{\prime}-\mathrm{GACTCGAGTCGACATCGAT}^{17}-3^{\prime}$ & & \\
\hline
\end{tabular}

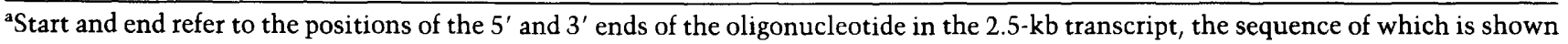
in Fig. 5.

'E4 is an oligonucleotide corresponding to sequences within the fifth intron of the 2.5-kb transcript and upstream of the most 5' splice site, which is spliced to SL1, of the $1.8-\mathrm{kb}$ transcript. The sequence of this oligonucleotide corresponds to nucleotides -43 to -27 upstream of the 1.8 -kb transcript $5^{\prime}$ splice site.

'The first 13 nucleotides of this oligonucleotide are a linker containing Xhol, SalI, and ClaI restriction sites. 
Table 2. Primer pairs used for PCR amplification of $c D N A s$

\begin{tabular}{|c|c|c|}
\hline Primer $1^{\mathrm{a}}$ & Primer 2 & $\begin{array}{c}\text { Size of PCR product } \\
\text { (bp) }\end{array}$ \\
\hline SL1 & E31 & $5651+1$ \\
\hline SL1 & E11 & $1241(\mathrm{P})$ and $624(\mathrm{P})^{\mathrm{c}}$ \\
\hline Eg2 & E11 & $1213(\mathrm{P})$ \\
\hline E4 & E11 & $6291+1$ \\
\hline E30 & $\mathrm{E} 12$ & $7901+1$ \\
\hline Eg5 & $\mathrm{dT}^{17}$ adaptor & $853 \mid+1$ \\
\hline
\end{tabular}

${ }^{a}$ Replacing the SL1 primer with a primer $\left(5^{\prime}\right.$-TCTAGAATTCCGCGGTTTTAACCCAGTTACTC-3') for SL2, a second 22nucleotide RNA that is trans-sliced to $C$. elegans transcripts (Huang and Hirsh 1989), yielded no detectable RT-PCR products.

bThe DNA sequence of either the whole PCR product $|+|$ or of the ends of the PCR product was determined $(\mathrm{P})$.

${ }^{\mathrm{C}}$ Because E11 lies within an exon shared by both the 2.5- and $1.8-\mathrm{kb}$ transcripts, amplification of cDNAs by PCR using this oligonucleotide and the SL1 oligonucleotide generated two products.

and 1.8-kb transcripts was labeled at its $5^{\prime}$ end with $\left[\gamma^{-32}\right.$ P]ATP and T4 polynucleotide kinase as described by Sambrook et al. (1989). The labeled oligonucleotide ( $2.5 \mathrm{fmoles}$ ) was hybridized to $5 \mu \mathrm{g}$ of poly $(\mathrm{A})^{+} \mathrm{RNA}$ in $10 \mu \mathrm{l}$ of a solution containing $0.4 \mathrm{M}$ $\mathrm{NaCl}, 40 \mathrm{~mm}$ PIPES (pH 6.4), and $1 \mathrm{~mm}$ EDTA at either $56^{\circ} \mathrm{C}$ or $65^{\circ} \mathrm{C}$ for $6 \mathrm{hr}$. The primer was extended with 200 units of murine MLV reverse transcriptase (BRL, Gibco) by use of standard techniques (Sambrook et al. 1989). The primer extension products were precipitated with ethanol and analyzed on an $8 \%$ polyacrylamide sequencing gel. Primer extension generated three products of 680,130 , and 74 nucleotides. The 680 - and 74-nucleotide products correspond well to the expected sizes for extension to the $5^{\prime}$ ends of the $2.5-\mathrm{kb}$ (685 nucleotides) and 1.8 -kb (76 nucleotides) transcripts, which are generated by trans-splicing to SL1. The 130-nucleotide product presumably corresponds to a transcriptional start site for the 1.8-kb RNA within the fifth intron. Consistent with this interpretation, the oligonucleotide used in this experiment (Kpe2) and a primer (E4) located just upstream from the $5^{\prime}$ splice site within the fifth intron could be used to amplify a PCR product from cDNAs (data not shown).

\section{Acknowledgments}

We are grateful to Cori Bargmann, Laird Bloom, Erika Hartwieg, Ed Hedgecock, James Ihle, Caroline Shamus, and Michael Shen for sharing unpublished data and to Josh Kaplan for suggesting the use of linkers for the frameshift experiment. We are also grateful to Barbara Meyer, Chantal Christ Akerib, and Mike Nonet for comments on this manuscript. This work was supported by U.S. Public Health Service research grant GM24663 to H.R.H and MH09926 to G.G. G.G. was supported by postdoctoral fellowships from the Damon Runyon-Walter Winchell Cancer Research Fund and the Charles A. King Trust. C.G. was supported by a Claire Booth-Luce University Fellowship and a National Science Foundation Fellowship. H.R.H. is an Investigator of the Howard Hughes Medical Institute.

The publication costs of this article were defrayed in part by payment of page charges. This article must therefore be hereby marked "advertisement" in accordance with 18 USC section 1734 solely to indicate this fact.

\section{References}

Brenner, S. 1974. The genetics of Caenorhabditis elegans. Genetics 77: 71-94.

Chalfie, M., J.N. Thomson, and J.E. Sulston. 1983. Induction of neuronal branching in Caenorhabditis elegans. Science 221: 61-63.

Chisholm, A. 1991. Control of cell fate in the tail region of $C$. elegans by the gene egl-5. Development 111: 921-932.

Clark, S.G., M.J. Stern, and H.R. Horvitz. 1992. C. elegans cellsignalling gene sem -5 encodes a protein with $\mathrm{SH} 2$ and $\mathrm{SH} 3$ domains. Nature 356: 340-344.

Clark, S.G., A.D. Chisholm, and H.R. Horvitz. 1993. Control of cell fates in the central body region of $C$. elegans by the homeobox gene lin-39. Cell 74: 43-55.

Costa, M., M. Weir, A. Coulson, J. Sulston, and C. Kenyon. 1988. Posterior pattern formation in C. elegans involves position-specific expression of a gene containing a homeobox. Cell 55: 747-756.

Delwel, R., T. Funabiki, B.L. Kreider, K. Morishita, and J.N. Ihle. 1993. Four of the seven zinc fingers of the Evi-1 myeloidtransforming gene are required for sequence-specific binding to GA/C/T)AAGA/T/C)AAGATAA. Mol. Cell. Biol. 13: $4291-4300$.

Desai, C. and H.R. Horvitz. 1989. Caenorhabditis elegans mutants defective in the functioning of the motor neurons responsible for egg laying. Genetics 121: 703-721.

Desai, C., G. Garriga, S.L. McIntire, and H.R. Horvitz. 1988. A genetic pathway for the development of the Caenorhabditis elegans HSN motor neurons. Nature 336: 638-646.

Fire, A. 1986. Integrative transformation of Caenorhabditis elegans. EMBO I. 5: 2673-2680.

Frohman, M.A., M.K. Dish, and G.R. Martin. 1988. Rapid production of full-length cDNAs from rare transcripts: Amplification using a single gene-specific oligonucleotide primer. Proc. Natl. Acad. Sci. 85: 8998-9002.

Garriga, G., C. Desai, and H.R. Horvitz. 1993. Cell interactions control the direction of outgrowth, branching, and fasciculation of the HSN axons of Caenorhabditis elegans. Development 117: 1071-1087.

Gray, G.E. and J.R. Sanes. 1991. Migratory paths and phenotypic choices of clonally related cells in the avian optic tectum. Neuron 6: 211-225.

Hatten, M.E. 1990. Riding the glial monorail: A common mechanism for glial guided neuronal migration in different regions of the developing mammalian brain. Trends Neurosci. 13: $179-184$.

Hedgecock, E.M., J.G. Culotti, J.N. Thomson, and L.A. Perkins. 1985. Axonal guidance mutants of Caenorhabditis elegans identified by filling sensory neurons with fluorescein dyes. Dev. Biol. 111: 158-170.

Hedgecock, E.M., J.G. Culotti, D.H. Hall, and B.D. Stern. 1987. Genetics of cell and axon migrations in Caenorhabditis elegans. Development 100: 365-382.

Hedgecock, E.M., J.G. Culotti, and D.H. Hall. 1990. The unc-5, unc- 6 , and unc- 40 genes guide circumferential migrations of pioneer axons and mesodermal cells on the epidermis in $C$. elegans. Neuron 4: 61-85.

Herman, R.K. 1978. Crossover suppressors and balanced recessive lethals in Caenorhabditis elegans. Genetics 88: 49-65.

Horvitz, H.R., S. Brenner, J. Hodgkin, and R.K. Herman. 1979. A uniform genetic nomenclature for the nematode Caenorhab- 
ditis elegans. Mol. Gen. Genet. 175: 129-133.

Huang, X.-Y. and D. Hirsh. 1989. A second trans-spliced RNA leader sequence in the nematode Caenorhabditis elegans. Proc. Natl. Acad. Sci. 86: 8640-8644.

Hynes, R.O. and A.D. Lander. 1992. Contact and adhesive specificities in the associations, migrations and targeting of cells and axons. Cell 68: 303-322.

Kenyon, C. 1986. A gene involved in the development of the posterior body region of C. elegans. Cell 46: 477-487.

Kimble, J. and D. Hirsh. 1979. The post-embryonic cell lineages of the hermaphrodite and male gonads in Caenorhabditis elegans. Dev. Biol. 70: 396-417.

Krause, M. and D. Hirsh. 1987. A trans-spliced leader sequence on actin mRNA in C. elegans. Cell 49: 753-761.

LeDouarin, N.M. 1982. The neural crest. Cambridge University Press. Cambridge, England.

Ma, J. and M. Ptashne. 1987. A new class of transcriptional activators. Cell 51: 847-853.

Manser, J. and W.B. Wood. 1990. Mutations affecting embryonic cell migrations in Caenorhabditis elegans. Dev. Genet. 11: 49-64.

Matsugi T., K. Morishita, and J.N. Ihle. 1990. Identification, nuclear localization, and DNA-binding activity of the zinc finger protein encoded by the Evi-1 myeloid transforming gene. Mol. Cell. Biol. 10: 1259-1264.

McIntire, S.L., G. Garriga, J. White, D. Jacobson, and H.R. Horvitz. 1992. Genes necessary for directed axonal elongation and fasciculation in Caenorhabditis elegans. Neuron 8: 307-322.

McIntire, S.L., E. Jorgensen, J. Kaplan, and H.R. Horvitz. 1993. The GABAergic nervous system of Caenorhabditis elegans. Nature 364: 337-341.

Mello, C.C., J.M. Kramer, D. Stinchcomb, and V. Ambros. 1991 Efficient gene transfer in C. elegans: Extrachromosomal maintenance and integration of transforming sequences. EMBO J. 10: 3959-3970.

Meyer, B.J. and L.P. Casson. 1986. Caenorhabditis elegans compensates for the difference in $\mathrm{X}$ chromosome dosage between the sexes by regulating transcript levels. Cell 47: 871-881.

Miller, D.M., M.M. Shen, C.E. Shamu, T.R. Burglin, G. Ruvkun, M.L. Dubois, M. Ghee, and L. Wilson. 1992. C. elegans unc-4 gene encodes a homeodomain protein that determines the pattern of synaptic input to specific motor neurons. Nature 355: $841-845$

Miller, J., A.D. McLachlan, and A. Klug. 1985. Repetitive zincbinding domains in the protein transcription factor IIIA from Xenopus oocytes. EMBO J. 4: 1609-1614.

Morishita, K., D.S. Parker, M.L. Mucenski, N.A. Jenkins, N.G. Copeland, and N.J. Ihle. 1988. Retroviral activation of a novel gene encoding a zinc finger protein in IL-3-dependent myeloid leukemia cell lines. Cell 54: 831-840.

Morishita, K., E. Parganas, C.L. Willman, M.H. Whittaker, H. Drabkin, J. Oval, R. Taetle, M.B. Valentine, and J.N. Ihle. 1992. Activation of EVIl gene in human acute myelogenous leukemias by translocations spanning $300-400 \mathrm{~kb}$ on chromosome band 3q26. Proc. Natl. Acad. Sci. 89: 3937-3941.

Nonet, M.L. and B.J. Meyer. 1991. Early aspects of Caenorhabditis elegans sex determination and dosage compensation are regulated by a zinc-finger protein. Nature 351: 65-68.

Pavletich, N.P. and C.O. Pabo. 1991. Zinc finger-DNA recognition: Crystal structure of a Zif268-DNA complex at $2.1 \AA$. Science 252: 809-817.

Perkins, A.S., R. Fishel, N.A. Jenkins, and N.G. Copeland. 1991a. Evi-1, a murine zinc finger proto-oncogene, encodes a sequence-specific DNA-binding protein. Mol. Cell. Biol. 11: 2665-2674.
Perkins, A.S. J.A. Mercer, N.A. Jenkins, and N.G. Copeland. $199 \mathrm{lb}$. Patterns of Evi-1 expression in embryonic and adult tissues suggest that Evi-1 plays an important regulatory role in mouse development. Development 111: 479-487.

Proudfoot, N.J. and G.G. Brownlee. 1976. 3' Non-coding regions in eukaryotic messenger RNA. Nature 263: 211-214.

Rakic, P. 1974. Neurons in the Rhesus monkey visual cortex: Systematic relationship between time of origin and eventual disposition. Science 183: 425-427.

Reichardt, L.F. and K.J. Tomaselli. 1991. Extracellular matrix molecules and their receptors: Functions in neural development. Annu. Rev. Neurosci. 14: 531-570.

Salser, S.J. and C. Kenyon. 1992. Activation of a C. elegans Antennapedia homologue in migrating cells controls their direction of migration. Nature 355: 255-258.

Sambrook, J., E.F. Fritsch, and T. Maniatis. 1989. Molecular cloning: A laboratory manual, 2nd ed. Cold Spring Harbor Laboratory Press, Cold Spring Harbor, New York.

Siddiqui, S.S. and J.G. Culotti. 1991. Examination of neurons in wild type and mutants of Caenorhabditis elegans using antibodies to horseradish peroxidase. $J$. Neurogenetics 7: 193211.

Sigurdson, D.C., G.J. Spanier, and R.K. Herman. 1984. Caenorhabditis elegans deficiency mapping. Genetics 108: 331345.

Singer, S. and A. Kupfer. 1986. The directed migration of eukaryotic cells. Annu. Rev. Cell Biol. 2: 337-365.

Stern, M.J. and H.R. Horvitz. 1991. A normally attractive cell interaction is repulsive in two C. elegans mesodermal cell migration mutants. Development 113: 797-803.

Sulston, J.E. and H.R. Horvitz. 1977. Post-embryonic cell lineages of the nematode Caenorhabditis elegans. Dev. Biol. 56: $110-156$

Sulston, J.E., E. Schierenberg, J.G. White, and J.N. Thomson. 1983. The embryonic cell lineage of the nematode Caenorhabditis elegans. Dev. Biol. 100: 64-119.

Wang, B.B., M.M. Muller-Immergluck, J. Austin, N.T. Robinson, A. Chisholm, and C. Kenyon. 1993. A homeotic gene cluster patterns the anteroposterior body axis of C. elegans. Cell 74: 29-42.

White, J.G., E. Southgate, J.N. Thomson, and S. Brenner. 1986. The structure of the nervous system of Caenorhabditis elegans. Philos. Trans. R. Soc. Lond. B Biol. Sci. 314: 1-340. 


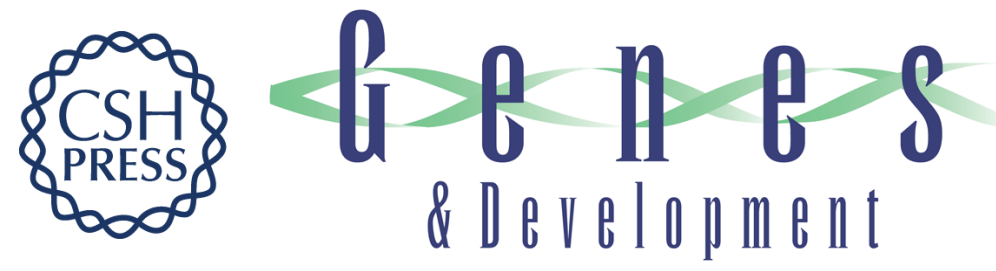

\section{Migrations of the Caenorhabditis elegans HSNs are regulated by egl-43, a gene encoding two zinc finger proteins.}

G Garriga, C Guenther and H R Horvitz

Genes Dev. 1993, 7:

Access the most recent version at doi:10.1101/gad.7.11.2097

References This article cites 51 articles, 18 of which can be accessed free at:

http://genesdev.cshlp.org/content/7/11/2097.full.html\#ref-list-1

License

Email Alerting

Service

Receive free email alerts when new articles cite this article - sign up in the box at the top right corner of the article or click here.

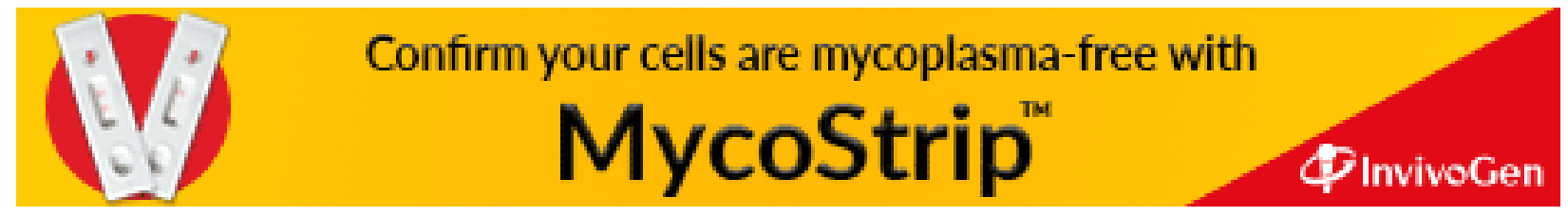

